Article

\title{
Images of Reality: Iris Murdoch's Five Ways from Art to Religion
}

\section{Elizabeth Burns}

Department of Philosophy, Heythrop College, University of London, Kensington Square, London W8 5HN, UK; E-Mail: e.burns@heythrop.ac.uk; Tel.: +44-020-7795-6600

Academic Editor: Jonathan Hill

Received: 8 May 2015 / Accepted: 13 July 2015 / Published: 30 July 2015

\begin{abstract}
Art plays a significant role in Iris Murdoch's moral philosophy, a major part of which may be interpreted as a proposal for the revision of religious belief. In this paper, I identify within Murdoch's philosophical writings five distinct but related ways in which great art can assist moral/religious belief and practice: art can reveal to us "the world as we were never able so clearly to see it before"; this revelatory capacity provides us with evidence for the existence of the Good, a metaphor for a transcendent reality of which God was also a symbol; art is a "hall of reflection" in which "everything under the sun can be examined and considered"; art provides us with an analogue for the way in which we should try to perceive our world; and art enables us to transcend our selfish concerns. I consider three possible objections: that Murdoch's theory is not applicable to all forms of art; that the meaning of works of art is often ambiguous; and that there is disagreement about what constitutes a great work of art. I argue that none of these objections are decisive, and that all forms of art have at least the potential to furnish us with important tools for developing the insight required to live a moral/religious life.
\end{abstract}

Keywords: Iris Murdoch; aesthetics; moral philosophy; religion

\section{Murdoch's Religion}

Iris Murdoch's account of the relationship between art, morals and religion is a response to the Christian doctrine of original sin, updated by Freud, which, for Murdoch, amounts to the claim that 
"[o]bjectivity and unselfishness are not natural to human beings" ([1], p. 51) ${ }^{1}$. She thinks that it is no longer possible to believe in God understood as a supernatural person ([3], p. 419); for Murdoch, "our sense of reality has shifted, we explain the world in new ways which cohere with all our new knowledge" ([4], p. 84). The method for overcoming human sinfulness which she therefore advocates is contemplation of the Good, a "principle of truthful cognition and moral understanding...a 'reality principle' whereby we find our way about the world" ([3], p. 474). She suggests that Plato's Trinity, consisting of the Forms, the Demiurge and the World Soul, is "more morally radiant than that of the Church" ([5], p. 52) because "[t]he image of a morally perfect but not all-powerful Goodness seems...better to express some ultimate (inexpressible) truth about our condition" ([5], p. 52). In addition, "the eternal separate inviolate Forms seem...a more profound image of moral and spiritual reality than the picture of a personal Father, however good" ([5], p. 52).

Nevertheless, although the Good is not another name for God, it is described using some of the attributes which have been traditionally ascribed to God-both God and the Good are "single perfect transcendent non-representable and necessarily real object[s] of attention" ([1], p. 55) — and the Good is regarded as a metaphor for the transcendent reality for which God is also a symbol ([1], p. 93; [3], p. 428). Indeed, Murdoch suggests that "Buddhism and Hinduism, even more 'picturesque' than Christianity, have always provided a variety of paths whereby their 'gods' can be seen as images of a higher reality" ([3], p. 451). Thus, the Good and God in Murdoch's thought have a common noumenal denominator ${ }^{2}$. Attention to the Good shows us general moral rules (for example, "do not lie", "be helpful", and "be kind" ([3], p. 302)), purifies our desires ([3], p. 109), and helps us to act well in every situation by enabling "the true and just seeing of people and human institutions, which is also a seeing of the invisible through the visible, the real through the apparent, the spiritual beyond the material" ([3], p. 475). For Murdoch, reality is "the object of truthful vision, and virtuous action...[is] the product of such vision" ([3], p. 39).

Although, for Murdoch, the Good is largely substituted for $\mathrm{God}^{3}$, she does appear to regard her position as religious. For Murdoch, "religion is...the passionate love of good" ([3], p. 326), and is concerned with "reconciliation and forgiveness and renewal of life and salvation from sin and despair" ([3], p. 129). She suggests that "Christianity can continue without a personal God or a risen Christ, without beliefs in supernatural places and happenings, such as heaven and life after death, but retaining the mystical figure of Christ occupying a place analogous to that of Buddha: a Christ who can console and save, but who is to be found as a living force within each human soul and not in some supernatural elsewhere" ([3], p. 419). Such a view, Murdoch suggests, "would preserve and renew the Christian tradition as it has always, hitherto, somehow or other, been preserved and renewed. It has always changed itself into something that can be generally believed" ([3], p. 419). To accomplish this, Murdoch thinks that it may "be necessary for philosophers to become theologians and theologians to become philosophers" ([3], p. 419).

1 A similar view is held by Roger Scruton, who suggests that " $\mathrm{t}]$ he Fall did not occur at a particular moment in time; it is a permanent feature of the human condition" ([2], p. 174).

2 Murdoch notes that Kant "removes God and the noumenal world, keeping them separate and safe outside the bounds of our knowledge, outside our "world", ([3], p. 423).

3 The terms sometimes appear to be used interchangeably-e.g., ([3], p. 109). 
Broadly speaking, Murdoch offers two philosophical arguments in support of her position. The first is a set of "arguments from experience concerned with the realism which we perceive to be connected with goodness" ([1], p. 75), which is developed in her chapter on the Ontological Proof in the Metaphysics as a Guide to Morals ([3], Chapter 13) ${ }^{4}$. I focus here on the second argument, "the love and detachment which is exhibited in great art" ([1], p. 75), an argument which is developed in Chapters 1, 4 and 5 of the Metaphysics but permeates much of her philosophical writing ${ }^{5}$. I suggest that this argument has five distinct but related strands, and argue that, taken together, these may be regarded as a cumulative case for the existence of the Good/God.

\section{Murdoch on the Relationship between Art and Religion}

Murdoch suggests that " $[\mathrm{t}]$ he Judaeo-Christian God owes a considerable debt to art, may even be seen as a work of art" ([3], p. 7), and that "[m]uch religious belief is like living in a work of art" ([3], p. 131). Indeed, she thinks, religion without art may be a kind of theological magic; "If we are to like religion we cannot be instantly confronted with nothing but the frightful austerity of what it is really asking!" ([3], p. 130) Murdoch argues that both the Christian Gospels and the writings of Paul may be understood as works of art. The Gospels "are the kind of great art where we feel: It is so" ([3], p. 128). Christ may be seen as "a universal tragic character" ([3], p. 125), and the Gospels show us "defeat turning into victory, the triumph of suffering over death, suffering set up as the adversary of death. The frightful story of Christ's death becomes a supreme cosmic event. The terrified confused abandoned disciples turn into heroes and geniuses. The story of Christ is the story that we want to hear: that suffering can be redemptive, and that death is not the end. Suffering and death are now joined in such a way that the former swallows up the latter. Suffering need not be pointless, it need not be wasted, it has meaning, it can be the way. The dying Christ redeems suffering itself, even beautifies it, as well as overcoming death" ([3], p. 128). Similarly, "Paul's writings, also great art, express a kind of demonic power, a sense of something being created before one's eyes by a force of inspired will, which convinces by rhetoric" ([3], p. 128). But even "[s]imple edifying religious homilies (as in sermons, Thoughts for the Day, etc.), using homely examples and excluding anything lofty or high-flown" may be regarded as "a clearly recognisable art form" ([3], p. 126).

Thus, for Murdoch, religious texts, religion, and perhaps even the Judaeo-Christian God, may be regarded as works of art. But Murdoch also argues that all great works of art are, in some sense, religious. Therefore, "[u]nderstanding what art is, its charms, its powers, its limits, helps us to understand religion" ([3], p. 83).

\section{Murdoch's Five Ways from Art to Religion}

Although Murdoch acknowledges "the fundamentally religious nature of Plato's objections to art...Art is dangerous [for Plato] chiefly because it apes the spiritual and subtly disguises and trivializes it" ([5], p. 65), she thinks that "Plato never did justice to the unique truth-conveying capacities of

4 I have discussed this argument in [6].

5 I am concerned here only with Murdoch's definition of great art, and her understanding of its function. For further discussion of the definition of art, please see, for example, [7-10]. 
art” ([5], p. 85). In this section, I identify five ways in which, according to Murdoch, great art supports moral/religious belief and practice.

\subsection{Art as Revelation}

For Murdoch, great art shows us "the world as we were never able so clearly to see it before" ([5], p. 78) by leading us towards "a juster, clearer, more detailed, more refined understanding of human nature, or of the natural world which crowds upon our senses" ([11], p. 90). For example, she suggests, Rubens' painting of the Last Supper shows Judas' dog sitting under his chair, which invites us to see him not simply as the villain whose action led to the death of Christ but as a sinful human being with redeeming qualities ([3], p. 86) - like other sinful human beings — and thus to conclude that human nature is never unambiguously good or bad.

Art also reveals to us "accident and contingency and the general muddle of life, the limitations of time and the discursive intellect", enabling us "to survey complex or horrible things which would otherwise appal us" ([3], p. 8). For Murdoch, the bad story is "the sentimental untruthful tale of how the brave attractive ego...triumphs over accident and causality and is never really mocked or brought to nought" ([3], p. 86). Bad art "misrepresents the world so as to pretend there is no defeat" ([3], p. 88), whereas "[a] study of good literature, or of any good art, enlarges and refines our understanding of truth" ([3], p. 86).

\subsection{Art as Evidence for the Existence of the Good/God}

In showing us the world as we have never seen it before, great art, Murdoch claims, enables us to deduce the existence of the principle which gave rise to such attentive perception, and helps us to attend to or contemplate it. Murdoch suggests that there is "something in the serious attempt to look compassionately at human things which automatically suggests that "there is more than this"'. This "there is more than this" is "a very tiny spark of insight" which has "a metaphysical position but no metaphysical form" and "great art is evidence of its reality" ([1], p. 73). According to Murdoch, a work of art "conveys...the idea of a transcendent perfection" ([3], p. 8). Indeed, "[t]he art object, transcendent, clarified, self-contained, alone, secure and time-resistant, shedding light upon the miserable human scene, prompting compassion and just judgment, seems like a picture of goodness itself, a sort of semi-sensory image of a spiritual ideal" ([3], p. 9).

Even great art can never constitute more than an imperfect image of Good/God, however, because it cannot give us an accurate representation of every aspect of the world. For example, it is unable to portray the extreme horrors of life: "[W] need only to reflect seriously upon really terrible human fates to see that they exceed art, are utterly different from art: bereavements...oppression, starvation, torture, terrorism, the father murdered in front of his child, the innumerable people who at this moment die of hunger in deserts and suffer without hope in prisons. And the fate of the Jews under Hitler which has become a symbol of the capacity and strength of human wickedness" ([3], p. 94). Art offers "some consolation, some sense, some form whereas the most dreadful ills of human life allow of none" ([3], p. 93).

Like art, religion can also offer consolation. It is "traditionally connected with bliss, whether as something to be attained hereafter or, by the elect, enjoyed in this life" ([3], p. 123). But, religion "also contains a self-transcending imperative, a continuous...urge to move beyond false consolation, 
suggesting a magnetic end-point where there is no more illusion, only truth" ([3], p. 124). It is for this reason that the highest forms of religion ultimately surpass even the greatest works of art in their ability to point towards the transcendent principle of Good/God ([3], p. 93).

\subsection{Art as a "Hall of Reflection"}

Art not only reveals the true nature of reality, thereby pointing beyond itself towards a transcendent guiding principle of goodness; it also provides us with opportunities to consider morally relevant situations. Murdoch suggests that art is "a great hall of reflection where we can all meet and where everything under the sun can be examined and considered" ([5], p. 86; [3], p. 8). Literary works, in particular, enable us to experiment with different fictional situations in order to try to understand them and discover appropriate courses of action so that, when we are required to act, we act well. Thus, by examining, for example, the accounts of Tamar's experience of abortion in Murdoch's novel The Book and the Brotherhood ([12], pp. 283-85, 322-30, 342-48, 364-68, 442-46, 449-51), we might be able to gain a better understanding of the nature of the moral dilemmas which such a situation can present, along with the emotional distress with which it may be associated, and thus to make a more reasoned assessment of the moral arguments concerning abortion than might otherwise have been possible. Although we may sometimes be able to gain the understanding which we need by means of direct personal experience of a similar situation, or, perhaps, from the accounts of others whose life-experiences differ from our own, no single person can gain all of their morally-relevant knowledge in this way. Furthermore, others' accounts of their experiences must necessarily be selective, and may possibly be embellished. As Murdoch observes, "even the man who is telling his wife what happened at the office, is confronted, whether he knows it or not, by questions concerning objectivity, impartiality, truth, justice" ([13], p. 254). Noël Carroll suggests, however, that "the way in which moral understanding is enhanced by narrative artworks need not be thought of as a matter of the fiction supplying readers with templates that they then go on to match to real cases." He cites the example of Mary Shelley's Frankenstein, which, for Carroll, shows us that evil is produced by the environment and social conditioning. Even though "[w]e are not in a position to measure real-life cases on a one-to-one basis against the story of Frankenstein... after reading the novel our moral understanding may be more sophisticated in such a way that we can identify cases of injustice quite unlike that portrayed in Frankenstein." ([14], pp. 146-47).

Carroll also notes that medieval theologians acknowledged the importance of examples for moral understanding in their recommendation of the use of the exemplum which can be traced to Aristotle's discussions of illustrations in his Rhetoric ([14], p. 146). Indeed, Carroll suggests, art "shares the thought experiment with philosophy" ([15], p. 137). But Martha Nussbaum argues that "[s]chematic philosophers' examples almost always lack the particularity, the emotive appeal, the absorbing plottedness, the variety and indeterminacy, of good fiction; they lack, too, good fiction's way of making the reader a participant and a friend" ([16], p. 46). She therefore suggests that we need "either side by side with a philosophical 'outline' or inside it - texts which display to us the complexity, the indeterminacy, the sheer difficulty of moral choice, and which show us...the childishness, the refusal of life involved in fixing everything in advance according to some system of inviolable rules" ([16], pp. 141-42). This function, Nussbaum argues, cannot be easily performed by philosophical texts that 
adopt a hard, plain style and speak in universal terms. Such texts, she thinks, fail to grasp the uniqueness of the particular, and cannot convey the complexity of the "matter of the practical" and "the active adventure of the deliberative intelligence, the 'yearnings of thought and excursions of sympathy' that make up much of our actual moral life?” ([16], p. 142, quoting [17], II.330)

\subsection{Art as an Analogue for World-Perception}

Art can also serve as an analogue for the way in which we should try to perceive our world. According to Murdoch, great art attempts to show us reality untainted by "the intrusion of fantasy", or "the assertion of self" ([1], p. 59). For example, she suggests that, unlike the Romantic novelists, great writers such as Scott and Tolstoy portray their characters as "free, independent of their author, and not merely puppets in the exteriorization of some closely locked psychological conflict of his own" ([18], p. 257). Shakespeare, being "the most invisible of writers", is the greatest exponent of such "tolerance" ([18], p. 261).

Rubin Rabinowitz objects that Murdoch fails to explain how self-involved writers such as Dostoyevsky still achieve greatness. He suggests that, on Murdoch's view, “one would expect [her own novel] The Sandcastle, containing fewer autobiographical elements than either Under the Net or The Flight from the Enchanter, to be the best novel of the three. But this book lacks the intensity and vividness of her first two novels, and a lack of subjective elements may even be one of the causes of the failure of The Sandcastle to involve the reader" ([19], p. 294). Murdoch does, indeed, acknowledge that "if you are not deeply personally engaged the work will be trivial". However, she continues, it is one of the paradoxes of art that "if you are it may be half blind" ([3], p. 103). Our sympathy for a character may lead us to ignore his faults; we may feel some affinity with the Prodigal Son, but this must be tempered by an awareness of the virtues of his brother ([3], p. 103). Thus, as Maria Antonaccio suggests, the task of the artist is not to "create a work that is a projection of her own fantasy or ego" ([20], p. 121), but to try to understand and portray accurately her characters' feelings, motivations and actions. The artist may sometimes be able to draw on her own experiences in depicting those of her characters, but she will use them only as a means of gaining insight, and will not inappropriately impose her own thoughts and feelings on her characters in their unique situations.

\subsection{Art and Self-Transcendence}

Lastly, Murdoch argues that art can help us to achieve self-transcendence, which is a necessary prerequisite for moral vision ([1], p. 85). For example, in her novel The Bell, Dora contemplates the pictures in the National Gallery which "were something real outside herself, which spoke to her kindly and yet in sovereign tones, something superior and good whose presence destroyed the dreary trance-like solipsism of her earlier mood" ([21], p. 191). The experience of self-transcendence may be described in ordinary words, such as "“All my anxieties fell away and I realized that what I was worrying about was not worth worrying about!' All the things that nag away at one, the fantasies of power or of revenge, anxiety, resentment and envy — all of this is what the revelation will blot out" ([22], p. 88).

6 Nussbaum acknowledges the connection between these ideas and Murdoch's argument in The Sovereignty of Good ([16], p. 142, note 19). 
It might be objected that Murdoch is merely advocating a kind of escapism for which great art is not required and Murdoch does, herself, acknowledge that "[a] sentimental novel can be a decent rest from one's troubles" ([23], p. 272). She also acknowledges that a similar function can be performed by beauty ([1], p. 84), or by the intellectual discipline required to learn a new skill ([1], pp. 88-89). Furthermore, it might be argued that self-transcendence is of limited moral/religious relevance since the loss of selfish concern does not necessarily lead to concern for others. Nevertheless, it might be argued that at least some measure of self-transcendence is necessary for us to achieve an understanding of the true nature of reality, and, specifically, of other people and their concerns. The attainment of self-transcendence does not, in itself, constitute a moral/religious achievement, but one cannot adequately understand reality unless one has attained it. As Antonaccio suggests, "[w]ithout undergoing the discipline of unselfing, what the artist or moral agent will produce is not a vision of reality, but rather her own fantasy — and hence bad art, or distorted perception" ([24], p. 159).

Thus we have seen that, for Murdoch, great art can show us the true nature of reality and, perhaps, the transcendent principle of God/Good to which it points. Great art also provides us with opportunities to reflect upon the nature of goodness, and can serve as an analogue for the way in which we should attend to the Good. Finally, it can also help us to transcend our selfish concerns and, thereby, to perceive more clearly the nature of reality and, perhaps, to glimpse the transcendent goodness which demands our attention. Murdoch's theory of art may therefore be described as a modified functionalist theory. If a functionalist theory is one which holds that "what makes something a work of art is a function it has" ([10], p. 116), then Murdoch holds that what makes something a great work of art is its capacity to lead us, in one or more of the five ways described in this section, towards a better understanding of the true nature of those aspects of reality which are relevant for our moral/religious development.

\section{Murdoch's Theory and the Forms of Art}

Heather Widdows objects that Murdoch's “conception of the type of art which helps us in the moral life is so terribly limited" ([25], p. 136) and Rabinowitz offers an expanded version of this objection. He suggests that Murdoch's theory can be applied to tragedy and fiction, but less well to comedy and poetry. Moreover, he thinks, when applied to painting, her aesthetic ideas are even less satisfactory: "One may insist on loving apprehension in a portrait, but how is loving apprehension to be distinguished from photographic realism in a still life or landscape? There is no use in even attempting to apply Murdoch's ideas to abstract painting or to music, and, wisely, she is silent on these topics" ([19], pp. 293-94) ${ }^{7}$. In fact, Murdoch mentions both abstract painting ([3], p. 12; [13], p. 256) and music ([1], p. 86; [5], p. 77), and says: "I take my theory to apply to all the arts and not just the literary arts. The notion of a loving respect for a reality other than oneself is as relevant to making a vase as it is to writing a novel, nor does the theory only apply to arts which involve, in the obvious sense, imitation" ([18], p. 54).

7 Carroll, too, suggests that "[s]ome absolute music and some abstract painting may be bereft of moral content altogether" ([16], p. 127). 


\subsection{Comedy and Poetry}

Contra Rabinowitz, Murdoch's theory can be applied without difficulty to comedy. As Murdoch herself points out, "The comic is capable of the highest seriousness, in life and in art" ([3], p. 92), and can even be revolutionary ([3], p. 91). She argues that, in the novel, comedy is capable of giving a portrayal of human life, which is more realistic that that found in tragedy. This is because "there is so much which is funny in life: especially if we extend our definition of 'funny' a little to include strange, incongruous, bizarre, ironic..." ([26], p. 15). Indeed, she goes so far as to describe the novel as "a comic form" ([27], p. 15; see also [3], p. 96). As Angela Hague observes, the comic artist can "include incoherent and unpredictable events in his work more freely than the writer of tragedy. It is comedy that admits the disorderly into art" ([28], p. 27). Murdoch suggests that comedy can, perhaps surprisingly, provide us with an accurate picture of suffering and death ([1], p. 87), and notes that people make jokes even in prison camps ([3], p. 97).

The "incoherent and unpredictable events" which are found in Murdoch's novels often consist of her characters' unexpected reactions to situations and people; for example, in The Italian Girl, Otto Narraway is overcome by laughter at his mother's funeral ([29], p. 22). Hague suggests that Murdoch does not intend such reactions to be seen as necessarily evil; rather, she is attempting to draw her readers' attention to the fact that such reactions are actually quite common ([28], p. 56). This interpretation is supported by Murdoch's defence of Dickens against the charge of exaggeration. She claims that "he just discerns how strange human beings are" and suggests that the function of the comic novel is to "emphasize truths which are normally concealed" ([30], p. 138).

On Murdoch's view, comedy not only reveals to us the true nature of reality; it also has a corrective function. According to Hague, in The Fire and the Sun Murdoch comes close to suggesting that being seen as absurd, or seeing oneself as absurd, is necessary in order to achieve humility and that this, in turn, increases our potential for goodness ([5], pp. 73-74; [28], p. 47). As Hague points out ([28], p. 47), in Henry and Cato, the priest Brendan Craddock tells Cato that an ignorance of our own absurdity actually creates evil: "Our chief illusion is our conception of ourselves, of our importance which must not be violated, our dignity which must not be mocked. All our resentment flows from this illusion, all our desire to do violence, to avenge insults, to assert ourselves. We are all mocked, Christ was mocked, nothing can be more important than that. We are absurdities, comic characters in the drama of life, and this is true even if we die in a concentration camp, even if we die on the Cross" ([31], pp. 158-59).

Murdoch's theory can also be applied to poetry. She remarks that "[a]11 tragedies are written in poetry...Tragedy is sometimes called the highest form of art because only great poetry can raise language to the pitch of clarified moral intensity which enables it to display the horrors of human life in dramatic form" ([3], p. 116). She suggests that "[o]ne might say of the Iliad that, in a supreme sense, it rises to a tragic level, which no prose work can reach" ([3], p. 93).

\subsection{Still Life, Landscape, and Abstract Painting}

Rabinowitz asks how loving apprehension can be distinguished from photographic realism in a still life or landscape. Murdoch claims that "[ $t]$ he realism of a great artist is not a photographic realism" ([1], p. 87), but one might, however, argue that, even, and perhaps especially, in a work of art which achieves 
photographic realism, an artist must respect his subject sufficiently to enable him to portray it accurately. Indeed, we have already noted Murdoch's claim that her theory is applicable to all the arts because they all involve loving respect for a reality other than oneself. In the Metaphysics she refers again to the artist's concern for transcendent objects, and her list of these includes both "things", and "landscapes" ([3], p. 5). Furthermore, respect or concern for the subject may be particularly clear when accurate representation is achieved at a personal cost much greater than that sustained by the photographer depicting the same scene. But even a photographer must choose her subject from an almost infinite range of possibilities and select the conditions in which she will photograph it, and this may require her to wait patiently until the desired natural conditions occur; thus, even the photographer may be able to show us the world as it has never been seen before. Nevertheless, it may be that there are other artists who, in their observance of detail, or in the way in which they draw our attention to a particularly significant aspect of the object of their perceptions, surpass that which can be achieved by the photographer. In the hands of these artists, both still lives and landscapes can be presented in such a way that their beauty or power is emphasized, thereby perhaps evoking in the viewer a sense of awe, or respect for nature, providing an analogue for moral perception, and enabling the self-transcendence without which such perception may not be possible.

As I noted above, Murdoch also thinks that her ideas can be applied to abstract painting. She holds that "[g]ood abstract paintings are not just idle daubs and scrawls, forms wandering around at random in spaces, they are somehow about light and colour and space" ([13], p. 256). The abstract painter is not "in a state of total freedom, he is relating himself to something else and his paintings exist for us in a world where we normally take colours to be parts of objects" ([13], pp. 256-57). Thus, Murdoch argues that, although abstract painting may not appear to represent the world, it can still communicate truths about the nature of both immanent and transcendent reality. In doing so, it may also provide us with an analogue for moral perception and enable the self-transcendence, which is a prerequisite for moral/religious belief and practice.

\subsection{Music}

Finally, it is also possible to apply Murdoch's theory to music, although Murdoch herself gives little indication of how this might be done. Indeed, she notes that " $[t]$ he spiritual role of music has often been acknowledged, though theorists have been chary of analysing it" ([1], p. 86). In some cases, music seems to direct our attention towards some morally relevant feature of reality. For example, Holst's "Mars", from The Planets suite, could be described as an attempt to portray the atmosphere of and evoke the emotions associated with war. In many cases, however, as Murdoch observes, “music doesn't seem to imitate nature except in some rather trivial sense" ([13], p. 243). Nevertheless, as we saw above, Murdoch does think that her theory applies not only to arts that involve imitation. Drawing on the work of Scruton and Jonathan Arnold, it may be possible to argue that great music, like other forms of great art, can direct our attention towards a reality the nature of which can enable us to transcend our selfish concerns, thereby effecting in us moral/religious change. Scruton suggests that "[m]usic offers us a pure aboutness that we can put to other uses, but which in its pure form has a kind of cleansing effect on the sympathetic listener: it opens us to sympathy, though with nobody in particular, readies us for the I-to-You encounter, though with nobody in particular, and speaks to us of another order of being than the one in which our embodied lives are trapped: an order of pure sympathy between subjects, without 
the encumbrance of an objective world. The useless space of music is, in Rilke's words, a godly home. It thereby offers an icon of the religious experience" ([2], p. 166). For Arnold, that which both sacred and secular music are about is "something greater than ourselves", ([32], p. 10), the transcendent or numinous; great music has the power to point us away from the ego and towards this, and, perhaps, to enable us to encounter it. He argues that great music gives us "not just a metaphor for the divine, but a totally different, non-verbal way of experiencing reality that is of great significance in our society, for those who are seeking to know more of the world than can be put into words" ([33], p. 153). He suggests that our musical experiences "will not give us scientific truths that we can take away as rational argument for, or against, the existence of the divine, but if we take the music seriously, we will be changed by what we have heard in a way that ultimately leads to the deepest truths of our reality: of joy, suffering, pain, loss, forgiveness, sacrifice, mortality and, ultimately, of love, which is God" ([33], p. 153). For Arnold, "[g]reat music... has the power to change us, by the renewal of mind, heart and soul" ([32], p. 10).

Thus, Murdoch's theory can indeed be applied to all forms of art. It applies to comedy and poetry as well as - if not better than - it does to tragedy and fiction, and I have argued that still life, landscape and abstract painting, as well as music, may be able to serve at least some of Murdoch's functions of great art - i.e., to reveal to us "the world as we were never able so clearly to see it before" ([5], p. 78), to point us towards a transcendent principle of Good, to serve as an analogue for the way in which we should try to perceive our world, and to enable the self-transcendence which is a necessary prerequisite for moral/religious belief and action.

\section{Further Objections}

\subsection{Art and Ambiguity}

Art's ability to reveal the nature of reality may be limited, however, because the significance of works of art, as Murdoch acknowledges ([22], p. 87), is often ambiguous. For example, it is by no means clear that the dog under Judas' chair in Rubens' painting of the Last Supper indicates a more than usually sympathetic treatment of Judas. Dogs were not well-regarded in the ancient world and the description "dog" was sometimes applied to Gentiles and evildoers. One possible interpretation is suggested by Matthew 15:26-27 [34]. In these verses, Jesus tells a Canaanite woman that "[i]t is not fair to take the children's food and throw it to the dogs" and she replies that "even the dogs eat the crumbs that fall from their master's table". We could argue that Judas represents the children who reject the teachings they are offered and that the dog represents the Gentiles who respond to the remaining "crumbs". Another possible interpretation may be derived from Revelation 22:15 in which dogs are listed with other sinners, including murderers and "everyone who loves and practices falsehood". In the light of this verse, Judas' association with a dog may be taken to indicate not his humanity but his sinfulness.

Murdoch also suggests that, in Titian's painting, "The Flaying of Marsyas", the expression of ecstasy on the face of Marsyas as he is flayed by Apollo provides us with an image of the death of the self, and that "you lose your egoism in this sort of agony" ([22], p. 89). Since, she suggests, "[r]eligion is about the death of the ego" ([22], p. 88), the picture may be described as "a sort of...religious icon" ([22], p. 89). But, even if we accept that this is the correct interpretation of the Apollo-Marsyas myth, its moral/religious teaching is by no means undisputed. Suffering does not always lead to the death of the 
self, since one may be too distressed by one's own pain to be concerned for others. Indeed, as John J. Burke points out, "[m]any Murdoch characters suffer, and suffer terribly, but they do not necessarily become purer or better because they suffer" ([35], p. 15).

Such ambiguity may, however, be presented in a more positive light. Murdoch suggests that the ambiguity of the moral significance of art and religion enables them to be appropriated by many individuals ([3], p. 98) and notes that, although moral philosophy may produce rules with the aim of achieving complete moral clarity, it is sometimes proper to stress the incomprehensibility of the world. She argues that "[c]ertain parables or stories...owe their power to the fact that they incarnate a moral truth which is paradoxical, infinitely suggestive and open to continual reinterpretation. (For instance, the story in the New Testament about the woman who broke the alabaster box of very precious ointment, or the parable of the prodigal son.) Such stories provide, precisely through their concreteness and consequent ambiguity, sources of moral inspiration that highly specific rules could not give. Consider too the adaptability which a religion may gain from having as its centre a person and not a set of rules" ([36], p. 91).

The biblical account of Moses' slaying of the Egyptian taskmaster (Exodus 2:11-14) provides us with an example of this. According to Brevard S. Childs, although Moses, in killing an Egyptian who was beating a Hebrew, acted out of love for his people, this was not clear to the man he subsequently rebuked for maltreating his fellow Hebrew. Further, the killing was carried out secretively and Childs questions "whether an act of justice can really be done under these circumstances" ([37], p. 183). Paul R. Noble points out that, although this story does not provide us with a neat answer to the question of whether one may use violence for the sake of justice, it does illustrate some of the problems that may be inherent in such a course of action. Noble argues that "someone who has understood this and other such stories will be better placed to evaluate the use of violence in the modern world, because through wrestling with these ancient texts one gains pertinent insights into...the unexpected misunderstandings and hidden consequences that such actions can have. ... through immersing oneself in the biblical world...one becomes aware of the appropriate questions to ask...even in situations that are far removed from any biblical parallels" ([38], pp. 356-57).

But even moral philosophy may be able to advance its aims more effectively by means of the careful employment of ambiguity. Earlier, I noted Nussbaum's suggestion that philosophical texts may need to be supplemented - either alongside or within them - by texts which display to us "the complexity, the indeterminacy, the sheer difficulty of moral choice" ([16], p. 141). Megan Laverty argues that, in order to do justice to the ambiguity of the human condition, philosophy itself must produce "visions and texts" which indicate "their own provisional nature" and their vulnerability to "opacities, conflicts and insufficiencies that are inherent in all such theories". Indeed, she suggests, philosophy must "become like great art" by drawing our attention to what Stephen Mulhall has called "the dense textures of the self and the material world" ([39], p. 36, quoting [40], p. 229). Laverty argues that Murdoch's comments on the literary quality of the writings of Plato and Schopenhauer imply that she herself deliberately changed her philosophical style from the concise arguments of The Sovereignty of Good to the more conversational style of the Metaphysics, in which "she has less control over the arguments and allows her thinking to range over a vast terrain" ([39], p. 47). She notes Murdoch's comment that Schopenhauer's relationship with his reader is "that of a kindly teacher or fellow seeker" ([3], p. 79) 
who is "prepared to exhibit his puzzlement and to ramble" ([3], p. 252), and to concede "the significance, magnitude and difficulty of the intellectual object that he faces" ([39], p. 47) ${ }^{8}$.

\subsection{Identifying a Great Work of Art}

Since, as Scruton has observed, for Murdoch "good art is the guide and counsellor of mankind", it is "one of the most important tasks of the philosopher to analyse the distinction between good and bad art” ([41], p. 38). But if, for Murdoch, one of the functions of good art is to communicate morally —and religiously - relevant truths about the nature of reality, how do we know when it has achieved this? We can tell whether a portrait accurately depicts its subject's physical characteristics by comparing it with the subject, but it is rather more difficult to know whether a painting is morally both significant and accurate. Marije Altorf objects that Murdoch "already knows - independent of any aesthetics — which works of art are the best, and that Shakespeare is "the greatest of all artists", and claims that "she subsequently judges aesthetics by the works of art it endorses" ([42], p. 78).

The problem is even more acute when applied to music. Colin Radford suggests that the music of Tchaikovsky is sentimental, and that this is a moral fault, whereas he finds in the music of Mozart both dignity and restraint ([43], pp. 432-33). Scruton, on the other hand, cites Tchaikovsky's sixth symphony as an example of a great work of art that makes a difference to our lives because it grants us "an intimation of the depth and worthwhileness of things". Although its message may be comfortless, "it is a comforting comfortlessness... a proof to the troubled listener that he is not alone" ([2], p. 173).

It might, perhaps, be easier to identify a work of art that is not, in Murdoch's sense, a great work of art—although even here there may be some room for disagreement. Carroll cites the film Natural Born Killers, which, he says, "advertises itself as a meditation on violence, but it neither affords a consistent emotional stance on serial killing, nor delivers its promised insight on the relation of serial killing to the media, if only because it neglects to show how the media might have affected the psychological development of the relevant characters. Indeed, its very title... would seem at odds with the hypothesis of media-made murder. The media references in the film seem to divert our attention from the moral issues at hand, and in confusing, or even perverting, our moral grasp of the issues, they are, along with the film as a whole, candidates for moral rebuke" ([15], p. 150). Scruton cites "disco music" in which "I-You intentionality is no longer the focus of attention"; instead, "the focus is entirely on repeated rhythmical figures, often synthesized digitally and without any clear musical performance, in which musical arousal is brought to an instant narcissistic climax and thereafter repeated. There is neither melody nor harmonic progression, but merely repetition, demanding no effort of listening and divorced from any relation with the external world" ([2], p. 151). One might, however, object at least to Scruton here, on the grounds that one cannot reasonably dismiss as unedifying a whole musical genre. The form of a pop song may not be as complex as sonata form but, like classical composers, contemporary songwriters do usually employ a standard structure within which there is much scope for variation of melody, harmony and harmonic development, and lyrics. No doubt there are poor performances of pop songs, just as there are poor performances of Mozart piano sonatas, but it might be argued that there is often a much greater degree of vocal variation in the performance of a pop song (such as Adele's

8 Cf. Nussbaum's suggestion that "Plato...saw clearly that the philosopher was an artist who created...a certain picture of the truth, and whose commitment to that creation led to the selection of a style that would be its fitting embodiment" ([13], p. 151). 
performance of "Someone Like You" ([44]), for example) than there is in a standard performance of a Mozart aria.

\section{Conclusions}

We have seen that, in order to overcome our "natural" human selfishness, for those who are unable to believe in God understood as a supernatural person, Murdoch recommends a "religion of the Good". Although the Good is not another name for God, it is a metaphor for the transcendent reality for which God was also a symbol. Murdoch recommends the "demythologisation" of religion, which, she thinks, "could bring religion back within the orbit of what an ordinary person can believe" ([13], p. 256), but warns against carrying this out "in too Feuerbachian a spirit", since this may lead to "losing too much while asserting too little" ([3], p. 460). For this reason, she thinks, "[t]he religious life and the imperfect institutions thereof should continue to represent the all-importance of goodness" ([3], p. 460).

In support of her interpretation of moral/religious belief and practice, Murdoch cites "the love and detachment which is exhibited in great art" ([1], p. 75). Indeed, following Tolstoy, she suggests "that good art is religious, that it embodies the highest religious perceptions of the age" and "that the best art can somehow explain the concept of religion to each generation" (cf. [9], p. 248; [45], p. 19). The work of the contemporary artist and the work of the contemporary theologian are therefore related ([9], p. 256) . For Murdoch, religious texts, and perhaps even religion itself, may be regarded as works of art, but all great works of art are, in some sense, religious. Understanding the nature of art can therefore help us to understand religion. I have argued that Murdoch's "argument from art to religion" has five distinct but related elements; art can reveal to us the true nature of reality; in doing so, it provides us with evidence for the existence of the transcendent principle of Good/God to which it points; it functions as a "hall of reflection", offering us opportunities to reflect upon the nature of goodness; it serves as an analogue for the way in which we should endeavour to attend to the Good; and, finally, it enables the self-transcendence without which we are unable to perceive the true nature of reality or to glimpse the transcendent principle of Good/God which demands our attention. As such, I would argue that it may be taken to constitute a cumulative case for the existence of the Good/God.

In response to three objections, I argued, first, that although some of Murdoch's critics have claimed that her theory applies only to a very limited range of art forms, it may legitimately be applied not only to the novel and some forms of painting but also to comedy, poetry, still life, landscape and abstract painting, and music. It may, however, be conceded that perhaps not all five elements of her argument apply to all forms of art. The "notion of a loving respect for a reality other than oneself" may be "as relevant to making a vase as it is to writing a novel" ([18], p. 54), but it is questionable whether even the most perfect of vases can provide us with "a great hall of reflection where we can all meet and where everything under the sun can be examined and considered" ([3], p. 8; [5], p. 86).

Secondly, it was suggested that moral/religious ambiguity may be regarded as a positive feature of works of art. As Murdoch herself claims, such ambiguity enables art to be appropriated by many moral agents in their differing situations, and may provoke a more wide-ranging debate about the nature of

9 Cf. Nicholas Wolterstorff's argument, derived from the work of Clive Bell, that art is related to the universal emotion which is found in a thousand creeds, and thus that the art lover and the mystic represent "twin manifestations of the spirit" ([46], p. 328). 
morality/religion and what they require of us than would otherwise be possible. Indeed, such ambiguity may even enable us to avoid the dangers often associated with fundamentalist attitudes towards morality and religious belief, since these attitudes may arise from a lack of awareness that our answers to questions about morality and religion are rarely certain and are often susceptible to ongoing revision.

Thirdly, while there may be some measure of agreement, there is no reason to expect that there must be a "once, for all time" decision regarding the nature and identity of great art. Just as, in the sciences, much of what we think of as "knowledge" changes and develops as the centuries pass, so it might be argued that it is the function of art critics, philosophers, theologians and religious practitioners to draw our attention to features of works of art which may have escaped our notice, and to stimulate an ongoing debate about the nature and identity of great art and of the moral and religious lessons which we can learn from it. It may, however, be important that there are no compelling reasons for regarding a work of art as morally/religiously misleading. Worryingly, Stanley Hauerwas expresses concern that Murdoch's own novels are a source of temptation for us because they train our perception in such a way that we lose "our capacity to acknowledge our created status" and "our ability to imagine any other world" ([47], p. 208). But this assessment, even if we are inclined to agree with it, indicates that Murdoch's novels contain features which stimulate debate about the requirements of morality and religion, thereby leading us to the conclusion that, in this respect at least, Murdoch's definition of great art may be applied to her own literary output.

Justin Broakes has suggested that Murdoch has transferred into her theory of art "the core of Kant's theory of the Sublime... The proper object of our feeling of elation at the unencompassable is not-as Kant supposes - the Alps or "the boundless ocean in a state of tumult"; it is the boundless variety of free persons, as (endlessly) revealed by love" ([48], p. 32, quoting [49], paragraph 28). This provokes not a sense of the superiority of Reason but humility and "the un-self-centred... agnosticism which goes with tolerance" ([18], p, 283, quoted in [48], p. 33), and this "has some of the character (as in Tolstoy) of a religious consciousness" ([48], p. 33). But even though, for Murdoch, religious texts and perhaps even religion itself may sometimes be regarded as works of art, in its purest form "religion lies beyond art" ([3], p. 93). Art offers us "some consolation, some sense, some form whereas the most dreadful ills of human life allow of none" ([3], p. 93). This means that "[t]he true religious life has no stories. It is above mythology." ([3], p. 91). Nevertheless, art can provide us with a ladder ${ }^{10}$ which takes us closer to our goal, whether this be conceived in terms of the Good or God, even if the nature of that goal means that the images that we create can never afford us more than occasional glimpses of the transcendent reality which guides our beliefs and practices.

\section{Acknowledgements}

I am grateful to two anonymous reviewers for their perceptive comments on an earlier draft of this paper.

\section{Conflicts of Interest}

The author declares no conflict of interest.

10 Murdoch notes Wittgenstein's claim that philosophical propositions are ladders to be thrown away after use at ([3], pp. 422-23). 


\section{References and Notes}

1. Murdoch, Iris. The Sovereignty of Good. London: ARK, 1985.

2. Scruton, Roger. The Soul of the World. Princeton: Princeton University Press, 2014.

3. Murdoch, Iris. Metaphysics as a Guide to Morals. London: Chatto and Windus, 1992.

4. Murdoch, Iris. Acastos: Two Platonic Dialogues. Harmondsworth: Penguin Books, 1986.

5. Murdoch, Iris. The Fire and the Sun: Why Plato Banished the Artists. Oxford: Oxford University Press, 1977.

6. Burns, Elizabeth. “Ontological Arguments from Experience: Daniel A. Dombrowski, Iris Murdoch, and the Nature of Divine Reality." Religious Studies 49 (2013): 459-80.

7. Adajian, Thomas. "The Definition of Art." In Stanford Encyclopedia of Philosophy. Stanford: Stanford University, 2012, pp. 1-26.

8. Currie, Gregory. "Actual Art, Possible Art, and Art's Definition." The Journal of Aesthetics and Art Criticism 68 (2010): 235-41.

9. Kamber, Richard. "Experimental Philosophy of Art." The Journal of Aesthetics and Art Criticism 69 (2011): 197-208.

10. Lopes, Dominic McIver. "Nobody Needs a Theory of Art." The Journal of Philosophy 105 (2008): 109-27.

11. Murdoch, Iris. "Ethics and the Imagination." The Irish Theological Quarterly 52 (1986): 81-95.

12. Murdoch, Iris. The Book and the Brotherhood. Harmondsworth: Penguin Books, 1988.

13. Murdoch, Iris. "Art Is the Imitation of Nature." In Existentialists and Mystics: Writings on Philosophy and Literature. Edited by Peter Conradi. New York: Penguin Books, 1999, pp. 243-57.

14. Carroll, Noël. "Art, Narrative, and Moral Understanding." In Aesthetics and Ethics: Essays at the Intersection. Edited by Jerrold Levinson. Cambridge: Cambridge University Press, 1998, pp. 126-60.

15. Carroll, Noël. Art and the Moral Realm. Edited by Peter Kivy. Malden: Blackwell, 2004, pp. 126-51.

16. Nussbaum, Martha C. Love's Knowledge: Essays on Philosophy and Literature. Oxford: Oxford University Press, 1990.

17. James, Henry. The Golden Bowl. New York: Charles Scribner's Sons, 1909.

18. Murdoch, Iris. "The Sublime and the Beautiful Revisited." Yale Review 49 (1959): 247-71.

19. Rabinowitz, Rubin. "Iris Murdoch." In Six Contemporary British Novelists. Edited by George Stade. New York: Columbia University Press, 1976, pp. 271-332.

20. Antonaccio, Maria. "Form and Contingency in Iris Murdoch's Ethics." In Iris Murdoch and the Search for Human Goodness. Edited by Maria Antonaccio and William Schweiker. Chicago: University of Chicago Press, 1996, pp. 110-37.

21. Murdoch, Iris. The Bell. Harmondsworth: Penguin Books, 1962.

22. Robson, Eric. "Iris Murdoch." In Revelations: Glimpses of Reality. Edited by Ronald S. Lello. London: Shepheard Walwyn and Border Television, 1985, pp. 82-90.

23. Magee, Bryan. "Iris Murdoch." In Men of Ideas: Some Creators of Contemporary Philosophy. London: BBC Books, 1978, pp. 264-84.

24. Antonaccio, Maria. A Philosophy to Live By: Engaging Iris Murdoch. Oxford: Oxford University Press, 2012.

25. Widdows, Heather. The Moral Vision of Iris Murdoch. Aldershot: Ashgate, 2005. 
26. Murdoch, Iris. "Speaking of Writing." The Times, 13 February 1964.

27. Rose, W. K. “An Interview with Iris Murdoch.” Shenandoah 19 (1968): 15.

28. Hague, Angela. Iris Murdoch's Comic Vision. Selinsgrove: Susquehanna University Press, 1984.

29. Murdoch, Iris. The Italian Girl. New York: Viking Press, 1964.

30. Bellamy, Michael. "Interview with Iris Murdoch." Contemporary Literature 18 (1977): 129-40.

31. Murdoch, Iris. Henry and Cato. New York: Viking Press, 1976.

32. Arnold, Jonathan. "The Language of God-Now More than Ever." In Church Times. London: Church Times, 2014.

33. Arnold, Jonathan. Sacred Music in Secular Society. Farnham: Ashgate, 2014.

34. New Revised Standard Version. Oxford: Oxford University Press, 1977.

35. Burke, Jr., John J. “Review of Iris Murdoch's Fables of Unselfing, David J. Gordon.” Iris Murdoch Newsletter 10 (1996): 15-17.

36. Murdoch, Iris. "Vision and Choice in Morality." In Existentialists and Mystics: Writings on Philosophy and Literature. Edited by Peter Conradi. New York: Penguin Books, 1999, pp. 76-98.

37. Childs, Brevard S. Biblical Theology in Crisis. Philadelphia: Westminster, 1970.

38. Noble, Paul R. The Canonical Approach: A Critical Reconstruction of the Hermeneutics of Brevard S. Childs. Leiden: E. K. Brill, 1995.

39. Laverty, Megan. Iris Murdoch's Ethics. London: Continuum, 2007.

40. Mulhall, S. "Constructing a Hall of Reflection: Perfectionist Edification in Iris Murdoch's Metaphysics as a Guide to Morals." Philosophy 72 (1997): 219-39.

41. Scruton, Roger. "Interior Design for the Examined Life." In The Times. London: The Times, 1997.

42. Altorf, Marije. Iris Murdoch and the Art of Imagining. London: Continuum, 2008.

43. Radford, Colin. "How Can Music Be Moral?" Midwest Studies in Philosophy XVI (1991): 421-38.

44. Adele Adkins, and Dan Wilson. "Someone Like You". Performed by Adele Adkins. London and New York: XL Recordings Ltd, 2011. DVD.

45. Magee, Bryan. "Literature and Philosophy: A Conversation with Bryan Magee." In Existentialists and Mystics: Writings on Philosophy and Literature. Edited by Peter Conradi. New York: Penguin Books, 1999, pp. 3-30.

46. Wolterstorff, Nicholas. "Art and the Aesthetic: The Religious Dimension.” In The Blackwell Guide to Aesthetics. Edited by Peter Kivy. Malden: Blackwell, 2004, pp. 325-39.

47. Hauerwas, Stanley. "Murdochian Muddles: Can We Get through Them If God Does Not Exist?" In Iris Murdoch and the Search for Human Goodness. Edited by Maria Antonaccio and William Schweiker. Chicago: University of Chicago Press, 1996.

48. Broakes, Justin. "Introduction." In Iris Murdoch, Philosopher: A Collection of Essays. Edited by Justin Broakes. Oxford: Oxford University Press, 2012, pp. 1-92.

49. Kant, Immanuel. Critique of the Power of Judgement. Edited and translated by Mary Gregor. Cambridge: Cambridge University Press, 1997.

(C) 2015 by the author; licensee MDPI, Basel, Switzerland. This article is an open access article distributed under the terms and conditions of the Creative Commons Attribution license (http://creativecommons.org/licenses/by/4.0/). 